\title{
Partition-Migration in Bengal: Political Schism and Regional-Cultural Divide
}

\author{
Golam Sarwar Khan \\ Department of Communication and Development Studies, The Papua New Guinea University of Technology \\ *Corresponding author: gkhan@1cs.unitech.ac.pg
}

Copyright (C) 2013 Horizon Research Publishing All rights reserved.

\begin{abstract}
A colossal influx of Hindus from East Bengal (EB) to West Bengal (WB) was evidenced as a consequence of communal riots and partition-migration during 1946-1947. In WB alone, an estimated 3 million uprooted EB Hindus became 'refugee-migrants' (coerced to flee their homeland and eventually settled as migrants). Initially, the EB Hindus were struggling to resettle in Kolkata and its vicinities. However, their resettlement effort was partially dented by the inimical attitude of the WB Hindus for economic reason. Socio-cultural issues further exacerbated the cleavage between the locals and the settlers. These factors resulted in a new phase of regional communal categorisation between the EB and WB Hindus against the conventional Hindu-Muslim conflict. Subsequently, regional differences and sense of exclusion were reflected in their attitudes of retaining own family values, marriage practices and distinct cultural identities. This paper attempts to analyse the EB Hindus' tendency of maintaining typical family norms and continuity of their cultural traits amidst the WB local culture in Kolkata. A theoretical discussion will be carried out on symbolic construction of community and social exclusion and variance.
\end{abstract}

Keywords Partition-migration; Communal categorization; Cultural identities; Symbolic construction

\section{Introduction}

An unplanned migration of both Hindus and Muslims in undivided Bengal eventuated at an exceedingly critical political juncture in British India during 1946 until August 1947. Statistics shows that the East Bengal (EB) Hindus fled to West Bengal (WB) in millions as compared to WB Muslims to EB. Hence, the partition-migration becomes evident as a consequence of the political division of Bengal and the creation of Pakistan in 1947. This 'unwilling or forced migration' of EB Hindus has impacted on their resettlement in WB, Kolkata in particular. In the literature, 'forced migration' [1] is also viewed as 'involuntary migration' that occurs due to a "catastrophic change in people's environment and they have little or no choice but to relocate. Causes range from natural disasters to sociopolitical upheaval"... [2]. Here the cardinal focus is on the migrants' problems of dislocation and their resettlement efforts in an unfamiliar geographic location.

Under such a precipitous political split, the significant regional-cultural dimensions of the EB Hindu migrants' status of refugee-hood should be explored [3]. In an effort to overcome the refugee status and to have permanent settlement, EB Hindu 'refugee-migrants'[4] struggle for resettlement in $\mathrm{WB}$, sustenance of family values and rigid regional identity has political overtones which call for an intensive investigation.

\section{Methodology}

For this research, necessary data and information were embraced using both primary and secondary sources. The primary sources comprised of fieldwork in south Kolkata employing qualitative research method.The qualitative investigation included participant-observation, in-depth interviewing and case studies in the sample location of south Kolkata. As for reference, the ethnographic characteristics of qualitative research and its legitimacy as qualitative interpretations of both traditional and post-modern perspectives were dealt in a number of ways [5-9]. In this particular qualitative inquiry, the subjective expressions of facts narrated by EB Hindus in the form of oral history were documented. These accounted for the struggle for resettlements encountering politics of exclusions and retention of regional and cultural boundaries. The secondary sources encompassed relevant written materials including, books, journal articles, periodicals, research reports, unpublished dissertations, government excerpts and website references.

\subsection{Theoretical context of symbolic cultural variance}

In contrast to WB Hindus' stable socioeconomic conditions, the EB Hindu refugee-migrants' vulnerable 
social position relating to their class background, caste hierarchy and generational values reflect a kind of conflicting hegemonic control over each other. With the passage of time, however, an interactive relationship has also developed between the migrants and the local residents which was socially constructed on the backdrop of symbolic cultural variance. Symbolic interactionism is a sociological perspective of self and society which concerns the state of human behaviour and attitudes in a given sociocultural conditions [10-14]. In this context, the central theme of symbolic interactionism is regarded as culturally derived social interaction. Considering the use of regional language and stereotypical cultural variants, the sense of symbolic interactionism tends to provide the basis through which social reality can be constructed. Hence, symbolic interactions are reflected in the physical environment relevant to certain human conduct under specific social conditions. Supposedly the symbolical relationships between the EB Hindu refugee-migrants and WB local Hindus in their beliefs, attitudes and regional-cultural motivations are revealed as "Bangal-Ghoti"[15]nexus of perceived rivalry. This regional identity issue entails an illustration of social conditions which could be either favourable through negotiations of both the parties or unfavourable for their rigid roles revealing symbolical differences. Contextually, the hegemonic relations of power and status disparities between Bangaland Ghoti can be assumed following the caste hierarchy of dominance. Thus it adheres to both symbolic and real societal situations reinforcing caste supremacy parallel toregional prejudice.

Finally, this sociocultural scenario disclosed the facts of conceptualising "Us and Them" or "They and We" feelings as long-standing beliefs and attitudes of both groups $[\mathbf{1 6 , 1 7 ]}$. Also, it can be contemplated as the "Insiders and Outsiders" views pointing at their origins of geographic regions which gradually implanted into social construction. The insider-outsider dynamics inculcated a kind of social status which is generally understood as symbolical. Referring to qualitative research, however, as a reality factor, it also indicated a critical reflection of status-quo in that insiders' position is termed as "holy-grail" while the outsiders' position is normally viewed as "problematic" $[\mathbf{1 8 , 1 9 ]}$. From the standpoint of one's social proximity and boundary maintenance, insiders are always in advantageous position than the outsiders (refugee-migrants) given the distinct regional identity. Even having the same religious belongings as well as similar ethnic backgrounds, both EB migrants and WB residents in Kolkata tend to differentiate each other at attitudinal and cultural levels.

\subsection{EB Hindus' resettlement efforts and politics of exclusion}

At the initial stage of their refugeehood, the EB Hindus had to struggle for their resettlement in Kolkata. Having the refugee-migrants' status and background, their traditional stereotypical values inhibited them from being exposed to metropolitan 'Kolkata Culture' [20]. In contrast to their counterpart WB local Hindus were wide-open in their social, economic, and political lives. In an effort to resettlement, the refugee-migrants attempted to meet social, economic, cultural and political needs. Observation suggests that in regard to family, marriage and caste/class relationships, migrants rigidly preferred to interact within their own regional communities only. Evidently for overall resettlement including housing and employment, however, the EB Hindus had to experience political unfairness. This state of iniquitousness indicated a kind of political exclusion.

The contra-relationships between the EB Hindus and the WB local Hindus relating to power and social domination, it appeared more symbolic given the conflict and consensus way of interacting with each other. In looking at power in a new dimension, Russell [21]conceptualised it basically in the same sense as that of the energy which is considered fundamental in physics. Here, the efficacy of social phenomenon [power] is compared to the laws of physics [natural and scientific]. Therefore, we may assume that the exercise of different forms of power in society, though socially constituted, has got its natural foundations as well.

Notions of differences were symbolically constructed over the years within two communities which could be traced back to historical background of political exclusion. For example, the Nehru-Liaquat Agreement [22] on Refugee issues that subsequently proposed for execution following the political partition of India and Pakistan.

The basic tenets of this agreement was that as soon as the communal rivalry, tension, violence and riots would be mitigated, Hindu migrants from Pakistan and Muslim migrants from India would return to their respective homelands and resettle in original places of their residence. This stated migratory status was just temporary. But there were hardly any evidences or viable statistics known on refugee-migrants who permanently returned to their place of origin (migrant Muslims from Pakistan to India or migrant Hindus from India to Pakistan). Therefore, the Nehru-Liaquat Pact in essence, exposed to as the unrealistic and utopian thought about communal problems since this problem had already taken a concrete shape of political aggrandisement in the Indian subcontinent on the event of partition-migration. The EB Hindus as the refugee-migrants were struggling for their resettlement in Kolkata who thought this Agreement as a preamble to political exclusion.

Note that, the bearers of dominant race, possessor of higher cultural norms and claimant of civilizational superiority can have citizenship status regardless of their migratory conditions. This kind of citizenship indicated the higher caste position of the migrants or economically affluent migrants. Primarily the proprietary rights, voting rights and rights to participate in political, religious, social and cultural activities considered as legal rights for citizens only. Hence, it is important to understand the role of citizenship, its meaning and usefulness in the context of migrants' lives relating to their exclusionary state (as being excluded, especially from mainstream society and its 
advantages) of political rights [23].

All in all, after a long enduring process of resettlement, the EB Hindu refugee-migrants in Kolkata have gradually attained the status of 'settled conditions' in their socioeconomic and political lives. Thus far, the sense of political exclusion could minimally affect the resettlement effort at its gradual decline against migrants' continual protest, resistance and relative economic success.

\subsection{EB family unity: regional firmness waned for economic advantage}

Despite diversified views on the development of highly globalized family patterns and processes around the world, even today the modern family is an important social institution which acts as the productive unit both biologically and economically. Family undertakes collectively various economic activities in order to support all its members $[\mathbf{2 4 , 2 5}$. The EB Hindu refugee-migrant families in Kolkata are characterized by the existence of joint-family patterns and extended family networks. In the process of resettlement, the EB Hindus tended to retain their family structures as "joint and extended". In fact, they initiated and carefully planned to carry on with the joint and extended family values. They intended that they should live in such family types to preserve their social existence. Such a family type is the composite of father-mother, grandfather, grandmother, sons, daughters, son-in-law, daughter-in-law, their children, and all live together under the same roof and share from the common pool of earnings. Narrated by the migrants [26-29], through their individual small-scale businesses in which every members of the family participates for income-generation. Such a united family enterprise involved very limited or no risk of uncertainty and distrust. Thus is clearly an indicative of the use of domestic labor-force. However, the underlying principle of carrying on these economic activities was nothing but to maintain EB regional family unity and firmness.

The introduction of employment for wages gives rise to the individual entrepreneurship and hence, the traditional protective character of the joint-family system gradually started to decline. Advancement of urban-industrial economy also contributed to the decline of the joint-family. Nuclear family emerged constituting husband-wife and their unmarried children. However, under nuclear family structure, the family values and practices as observed among the WB Hindus, for all practical purposes, were not favorable for the EB Hindu migrants' resettlement efforts[30]. Hence, there was a conflict of family values within these two communities.

Both EB and WB Hindus were less likely to have marriage contracts with each other because of differences in family structure and preferences in terms of matrimonial contracts. However, in some cases the matrimonial contracts eventuated between them when Ghoti could find a bridegroom from the EB Hindu refugee-migrants living outside the joint-family structure. For example, a Ghoti family would prefer a Bangal bridegroom who has a good job and lives alone outside Kolkata because, the Ghoti family's daughter will not have to live with the bridegroom's extended family since he works outside Kolkata. Here, the question of self-centred individuality is prominent with the Ghoti family values. On the other hand, the Bangal's priority in settling matrimonial contracts is for consolidating the economic power and maintaining regional identity. They hardly consider self-centred individuality in matrimonial contracts, because they have not developed such family values while living in the joint and extended family environment. EB Hindus prefer regional identity and class instead of caste priority in matrimonial contacts. One of the reasons being that many of the migrant families belonged to lower castes. Over the years, the EB Hindus tended to compromise on regional inflexibility for economic advantage and for gaining elevated social status through marriage deals with the WB Hindus [31-33].EB migrants' retention of strict regional identity is no longer a determining factor for marriage and thus they can conveniently take a departure from regional barriers.

\section{Conclusion}

Partition-migration was inevitable at a certain stage of political predicament in undivided Bengal. The extreme form of political turmoil was observed, that flared up with the severe Hindu-Muslim communal rivalry, riots and brutal killings during 1946 unto July 1947 in both eastern and western Bengal. Looking at the historical facts of Indian subcontinent in general and Bengal in particular, as a consequence of supposedly artificially created communal distrust along with indicative political overtones; millions of EB Hindus involuntarily fled to Hindu majority region of West Bengal, Kolkata in particular. Although interpreting it as Hindu-Hindu reflection, EB Hindus were barely welcomed and thus struggled for resettlement for decades. Evidently, having out-group status as politically marginalised, the EB Hindus inclined to emancipate by inculcating strategic communal homogeneity. To this end, they endeavoured to promote domestic labour-force and regional-cultural divide through matrimonial contracts for a considerable span of time until they achieved relatively settled status in Kolkata. The gradual increase in the settled status of EB Hindus in Kolkata reduced the attitudinal differences between Bangals and Ghotis in regard to regional-cultural distinctiveness.

\section{REFERENCES}

[1] For a detailed focus on 'forced migration', refer toRobinson "Forced Migration", in Boyle, et al. (eds.) Exploring Contemporary Migration, Harlow, Engl. Addison Wesley Longman: USA, 1998, 180-206. 
[2] Hansen, A. and Oliver-Smith, A. (eds.), Involuntary Migration and Resettlement: The Problems and Responses of Dislocated People, Westview Press, Colorado: USA, 1982.

[3] Bose, P.K. (ed.), Refugees in West Bengal: Institutional Practices and Contested Identities, Calcutta Research Group, Calcutta: India, 2000.

[4] Here 'refugee-migrants' are meant to be EB Hindus who were compelled to leave their homeland and finally settled as migrants in WB.

[5] Bogdan, R.C. and Biklen, S.K.,Qualitative Research for Education: An Introduction to Theory and Methods, Allyn and Bacon,Boston: USA, 1992.

[6] Eisner, E.W., The Enlightened Eye: Qualitative Inquiry and the Enhancement of Educational Practice, Macmillan, New York: USA, 1991.

[7] Marshall, C. and Rossman, G.B.,Designing Qualitative Research (3rd ed.), Thousand Oaks, CA: Sage, USA, 1999.

[8] Rossman, G.B. and Rallis, S.F.,Learning in the Field: An Introduction to Qualitative Research, Thousand Oaks, Sage, CA: USA, 1998.

[9] Denzin, N. K., \& Lincoln, Y. S., Handbook of Qualitative Research (2nd ed.), Thousand Oaks, Sage Publications, CA: USA, 2000.

[10] Cooley, C.H.,Human Nature and the Social Order, Scribner, New York: USA, 1902.

[11] Thomas, W.I., The Unadjusted Girl, Little Brown, Boston: USA, 1931.

[12] Mead, G.H., Mind, Self \& Society from the Standpoint of a Social Behaviorist, University of Chicago Press, USA, 1934.

[13] Goffman, E., The Presentation of Self in Everyday Life: Anchor Books, USA, 1959.

[14] Blumer, H.,Symbolic Interactionism: Perspective and Method, Englewood Cliffs, NJ: USA, 1969.

[15] The term "Bangal-Ghoti" is generally used to mean as the variance in their accents/dialects of spoken Bengali language in East Bengal (Bangal) and West Bengal (Ghoti). However, their separate geographic habitations of long-standing also revealed cultural distinctiveness significantly.

[16] Peter, I.R., They and We: Racial and Ethnic Relations in the
United States: Paradigm Publishers, USA, 2005.

[17] Berreby, D.,UsandThem: TheScienceofIdentity, University of Chicago Press, USA, 2008.

[18] Martiniello, M. \& Rath, J. (eds.), Selected Studies in International Migration and Immigrant Incorporation, Amsterdam University Press, The Netherlands, 2010.

[19] Mullings, B., Insider or Outsider, Both or Neither: Some Dilemmas of Interviewing ina Cross-Cultural Setting, Syracuse University: USA, 1999. Geoforum (30) 337-350.

[20] 'Kolkata Culture' usually meant to understand one's participation and commitment to the spirit of consumerism, pursuance of impersonal relationship, modern approach towards family, free of caste prejudices and access to political life as well.

[21] Russell, B.,Power: A New Social Analysis,Allen \& Unwin, London: UK, 1938.

[22] Government of India,"Nehru-Liaquat Agreement", Ministry of External Affairs, New Delhi, India, 1950.

[23] Kapur, R., "The Citizen and the Migrant: Postcolonial Anxieties, Law, and the Politics of Exclusion/Inclusion," Theoretical Inquiries in Law: Vol.8: No. 2, Article 8.(2007). Available at: http://www.bepress.com/til/default/vol8/iss2/art8. Accessed on January 3, 2013

[24] Mandelbaum, D. G., Society in India, Popular Prakashan, Bombay: India, 1970.

[25] Yorburg, B., Family Realities: A Global View, Prentice Hall, New Jersey: USA, 2002.

[26] Interview: Das, S. 2001;

[27] Interview: Dey, A. 2001;

[28] Interview: Pal, M. 2001;

[29] Interview: Roy, A. 2002;

[30] Khan, G.S.,New Life, New Home: A Story of Retaining the Cultural Boundaries, Common Ground Publishing, Illinois Champaign: USA, 2009.

[31] Interview: Rakshit, S. 2000;

[32] Interview: Banerjee, P. 2001;

[33] Interview: Bhowmik, N. 2002. 